\title{
Female Immigrant Entrepreneurship in Germany
}

\author{
David B. Audretsch ${ }^{1}$, Erik E. Lehmann² and Katharine Wirsching ${ }^{3}$
}

\begin{abstract}
The recent waves of immigration in western countries lead to challenges for policy makers and the society. In particular the integration of immigrants into the society and the labor market is intensively discussed. Within this process, self-employment and entrepreneurship plays an important role, and in particular new venture creation by women. This chapter aims to provide a snapshot on female entrepreneurship in Germany, with a focus on female immigrant entrepreneurship. We analyze female immigrant entrepreneurship against its historical background as well as in the light of the recent 'European refugee crisis'. In this chapter we analyze differences between opportunity-driven and necessity-driven female immigrant entrepreneurship and how these differences matters for policy makers. We identify barriers based on personal characteristics, attitudes, cultural background and the entrepreneurial environment hindering latent and nascent female entrepreneurs to start new ventures and thus make a successful process of integration difficult. Despite the emergence of female immigrant entrepreneurship as an academic topic, there exists only scarce and almost anecdotal evidence for Germany. Thus, this chapter aims to present some facts and figures to shed some light on the current situation and development potential to stimulate further research on this topic.
\end{abstract}

Key words: female entrepreneurship, immigrant entrepreneurship

JEL: J15, J61, L26

A revised version of this paper is published as 'Audretsch, D., Lehmann, E.E. \& Wirsching, K., Female Immigrant Entrepreneurship, in Link, A. N. (Ed.): Gender and Entrepreneurial Activity, Edward Elgar Publishing, 2017, 46-68'. Please refer to the published version. http://www.eelgar.com/shop/gender-and-entrepreneurial-activity

\footnotetext{
${ }^{1}$ David B. Audretsch, Distinguished Professor and Ameritech Chair of Economic Development Institute for Development Strategies, Indiana University, Indiana 47405 USA. daudrets@indiana.edu.

${ }^{2}$ Erik E. Lehmann, University of Augsburg and CCSE (Augsburg/Bergamo, It), Faculty of Business and Economics,

Universitaetsstr. 16, 86159 Augsburg, Germany. e-mail: erik.lehmann@wiwi.uni-augsburg.de.

${ }^{3}$ Corresponding author: Katharine Wirsching, University of Augsburg, Faculty of Business and Economics, Universitaetsstr.

16, 86159 Augsburg, Germany. e-mail: katharine.wirsching@wiwi.uni-augsburg.de.
} 


\section{Introduction}

According to a recent report of the Organisation for Economic Co-operation and Development (OECD) on migration (OECD, 2015a), Germany is one of the main origin countries of emigrants and has the second highest amount of immigration. In 2011 about 3.4 million people originally from Germany were living in other OECD countries like the United States, the United Kingdom and Switzerland (OECD, 2015b). On the other hand, over the past decades traditionally many more foreigners immigrated to Germany than emigrated. In 2012 Germany was ranked second among receiving countries for permanent immigrants with about 400,000 people, directly following the United States (OECD, 2015a). The statistics on net migration have been consistently positive for more than 25 years with only two exceptions (2008 and 2009), which could be attributed to changes in the registration of Germans' social security numbers (Statistisches Bundesamt, 2016). Consequently, Germany can be designated as an immigration country with a long tradition, starting in the 1950s and the 1960s, when the political leadership decided to actively recruit so-called guest workers to fulfill the German 'Wirtschaftswunder' (see Audretsch and Lehmann, 2016, pp. 46ff.). Thus, without migration in the past and the present, Germany would not be one of the leading Economies in Europe.

The advantages of migration for the host countries are, however, associated with challenges for politics and society. In particular, integrating immigrants into society and the labor market is challenging. Integration problems not only occur because of legal restrictions, heterogeneous skills and languages, but also as a result of cultural and religious differences, which often act as barriers for entering the labor market. Immigration in the last few decades has not been a continuous phenomenon but occurs in waves. Such waves often congest the labor market, in particular for low-skilled workers, and thus hinder the integration of immigrants into society. One important way to solve the 'society-immigrant' integration problem is through entrepreneurship and self-employment. Entering the labor market requires different skills and abilities, which have to be learned and improved, and are less important for self-employment and new venture creation. Countries such as the United States or the United Kingdom with traditional high percentages of immigrants have for some time drawn the attention of researchers and policy makers on the importance of ethnic minority and immigrant entrepreneurship, and in particular the role of women. The sparse evidence from this hitherto under-researched topic points out that ethnic minority women are to a large extent more entrepreneurial than their white female counterparts (Harding, 2004; Harding and Bosma, 2006), and in particular are more active than their male relatives. These factors should allow a 
shift in policy-maker focus onto the role of female entrepreneurship as an effective mechanism to integrate immigrants into society. First, ethnic minority females differ in large from their male relatives in relation to their ethnic network, their access to financial and emotional support, and thus their ability for and willingness to engage in self-employment and new venture creation (Aldrich, Resse and Dubini, 1989; Verheul and Thurik, 2001). Second, the assumption that all migrations from politically instable countries such as Syria or Afghanistan are permanent is not supported by the empirical evidence (see Dustmann and Görlach, 2016). From the original 400,000 refugees from Yugoslavia, only a small proportion, less than 10 percent, are still living in Germany. The other 90 percent left Germany in the following years, most of them returning to their home country. Depending on the country and time period considered, about 20 to 50 percent of immigrants leave the host country within five years of arrival (Dustmann and Görlach, 2016). For this temporary migration, self-employment and new venture creation could be an effective solution to improve the immigrants' existing circumstances and to invest in their personal futures.

Overall, one in five German citizens has a migration background, which means that she/he, or at least one of her/his parents, was born outside of Germany or as a foreigner in Germany and therefore has a different nationality (Bundesamt für Migration und Flüchtlinge, 2015). Past research suggest that these minorities utilize their skills and potential and more often go into business for themselves. In addition, they also have difficulties entering the regular labor market. These entrepreneurial activities are classified as necessity-driven and trace back to the fact that becoming entrepreneurs provides their only opportunity to cover their living costs. The gender of an immigrant is generally not a criterion for entry, and as far as forced migration is concerned, we know from the past that women are overrepresented. Special effort is needed to integrate these immigrants into the labor market, either with employee status or as entrepreneurs. If these female refugees from mainly developing countries have to compete with other candidates for working places, starting their own business might be a particularly good way forward. Ács et al. (2011) argue that entrepreneurship in developing and developed countries differs for institutional, economic and social reasons, and that these circumstances and environments must be taken into account when it comes to policy implications. This holds not only for countries, but also for the different needs and requirements of necessity-driven versus opportunity-driven entrepreneurs. Through examining immigrant entrepreneurship in Germany, it can be seen that cultural characteristics from developing and developed countries, such as role models, practices, or rules based on religious or social demands, impact each other and thus need to be taken into account. 
Analyzing these challenges, disadvantages and discriminations should help to improve policy interventions and therefore the entrepreneurial environment for female immigrant entrepreneurs. Apart from a general review of the literature, the aim of this chapter is to investigate how female immigrant entrepreneurship developed in the last 15 years and how it shapes economic and social welfare in Germany. In the remainder of the chapter we present why immigration is a historical phenomenon in Germany and examine the degree of its impact on economic welfare. Against this backdrop, the entrepreneurial landscape in Germany as well as policy efforts and programs are discussed. Some facts and figures draw a picture of the current distribution of the German working population including ethnical backgrounds and employment relationships. This chapter first addresses the theoretical background of female immigrant entrepreneurship and discusses barriers and obstacles. The second part of the chapter focuses on the current situation of female immigrant entrepreneurs in Germany. A summary concludes the chapter.

\section{Immigration and Entrepreneurship in Germany: a Snapshot}

The German Federal Office for Migration and Refugees defines migration as a situation where 'a person changes the location of their usual place of residence. International migration occurs when this movement crosses national boundaries' (Bundesamt für Migration und Flüchtlinge, 2006). Germany has a long tradition of being a receiving country for immigrants from all over the world. Since long before 1871 (when the German countries where unified under Bismarck), sovereigns like the former kings of Prussia used migration, such as the Huguenots refugees from France, as an active policy instrument to shape regional wealth and growth. The city of Mannheim was populated by immigrants from several nations after the Thirty Years' War ${ }^{4}$. Likewise, the Saarland, a federal state of Germany, was populated with immigrants after a French invasion in the 17th century. In the present day, Germany's historical background as well as its entrepreneurial landscape attracts entrepreneurs from developing and developed countries, encouraging them to realize their business ideas in Germany. The following section shows why to some extent this development is surprising and how Germany has changed its policy interventions over the last decades.

\footnotetext{
${ }^{4}$ This planned diversity led to a creative climate making Mannheim one of the most innovative cities in the world with important inventions like the bicycle (Karl Drais), the automobile (Carl Benz), large-engine tractors (Karl Lanz) and new chemicals (Friedrich Engelhorn, founder of BASF).
} 


\subsection{Migration: Historical Background and Current Situation}

In the 1950s and 1960s, German political leadership supported labor migration to reinforce the economy. Initially, these migrant workers were only allowed to work in dependent employment positions and came from the so-called recruitment countries (Anwerbeländer) such as Italy, Greece, Spain, Turkey and Tunisia. At that time, these workers were called 'guest workers', which reflected their social and political standing and implied that they would go back to their original countries after a couple of years. In the 1970s, migration laws and policies changed and many of the workers received an 'unlimited permit of residence', which implied the right to establish an own business and start self-employment. From this time, many ethnic workers started the reunification of their families, which led to growing ethnic communities. Ethnic entrepreneurship arose from these communities and was forced by growing unemployment induced by the oil crisis and economic recession (El-Cherkeh and Tolciu, 2009; Kontos, 2003; Leicht and Langhauser, 2014).

Two entrepreneurial success stories in Germany date back to this migration wave, shaping both cultural life and immigrant employment. Just as Marco Polo is said to have changed cuisine in Italy by bringing pasta from China to Italy, cuisine in Germany has been shaped by two inventions, the doner kebab and the spaghetti ice. Doner kebab is a Turkish dish made of meat cooked on a vertical rotisserie, normally lamb but also a mixture of veal or beef with this or sometimes chicken and turkey. Doner stands for 'turn around' and means that the beef is roasted on a vertical rotisserie. While the dish is widely known by its Arabic name 'shawarma' or the Greek name 'gyros', doner kebab is said to be a German invention dating back to the 1970s in Berlin. The story tells that Turkish immigrant Kadir Nurman first served the roasted lamb wrapped in a flat bread like a pita and served it with onions only. He opened his first doner kebab diner in Berlin Bahnhof Zoo (Möhring, 2012, pp. 385ff.). This is confirmed by the Association Turkish Döner Producers. He sold his diner in 1972. Today more than 60,000 people, almost all immigrants, are either busy serving doner in over 16,000 doner diners or preparing the ingredients (Spiegel online, 2011). Sales in this industry are estimated to be 3.5 billion Euros annually, and doner has been exported to Austria, Switzerland and Liechtenstein since the 1990s (Frankfurter Rundschau, 2011). The dissemination and success of the doner kebab in Germany and its neighbors resulted from one fatal error - Nurman forgot to patent his invention ${ }^{5}$.

\footnotetext{
${ }^{5}$ In 2011 he was rewarded by the Association of Turkish Döner Producers. Kadir Nurman passed away in 2013. The media dignified him as a person shaping German culture and life and thus bringing together Turkish and German people. See
} 
The second success story refers to Dario Fontanella, the inventor of the spaghetti ice in Mannheim in the late 1960s. Spaghetti ice is a German ice cream made to look like a plate of tomato spaghetti with parmesan cheese. In the dish, vanilla ice cream is extruded through a modified press or potato ricer, giving it the appearance of spaghetti. The trick is quite simple: the potato ricer or press must be cooled before; otherwise, you only receive frozen mud (Stern, 2014). It is then placed over whipped cream and topped with strawberry sauce to simulate tomato sauce. Coconut flakes, grated almonds or white chocolate shavings then represent the parmesan cheese (Fontanella, 2016). Although it is not well known outside Germany, it can be found at some gelaterias (ice cream parlors), at special events, and at some hotels and restaurants around the world. Fontanella also forgot to patent his invention - he wanted to save the money (900 DM, about 450 Euros) (Fontanella, 2016). Sales of spaghetti ice are hard to estimate. Every little town in Germany hosts at least one gelateria selling spaghetti ice. Around the spaghetti ice, an industry has been established selling special kind of plates, presses, spoons and other accessories.

A second wave of immigrants arrived in the late 1980s and the early 1990s. Many people from the former state of Yugoslavia applied for asylum because of the war in their home country. The peak of 440,000 applications in 1992 led to political reactions; as a consequence, the right of asylum was modified such that asylum seekers from so-called safe third countries no longer have the right to stay in Germany under asylum. A new determination and classification of the 'safe countries' is currently again under discussion and seen as a solution to manage the so-called European migrant crisis.

Not only because of Germany's geographic position in the middle of Europe and its economic welfare, but also because many foreigners already had relatives or friends in the country, since the second half of 2015 more than 1.1 million refugees from Syria, Kosovo, Afghanistan, Eritrea and their countries have arrived in Germany to seek asylum (Bundesamt für Migration und Flüchtlinge, 2016). This third wave of immigrants, mainly caused by terrorism and civil wars in African countries, Syria and Afghanistan, exceeds the previous waves in size. How these immigrants can be integrated into society as well as the world of employment is one of the major challenges Germany faces in the coming years. Many of these immigrants are young males, but also females and whole families reached Germany, primarily for security when there were humanitarian emergencies.

http://www.spiegel.de/panorama/gesellschaft/doener-erfinder-kadir-nurman-ist-tot-a-930140.html (accessed 10 December 2014). 
Once safely arrived, these refugees try to settle down and integrate into society as well as working life. The migrants have different educational backgrounds, professional experiences and skills, which could be an opportunity to produce a positive impact on overall economic development and the integration process as a whole. One of the most important challenges for the next few years will be to recognize and nurture their capabilities and talents.

Besides the conflict-induced immigration, domestic migration within the European Union (EU) and beyond brings people from countries like Poland, Romania, Bulgaria and Croatia to Germany. They have a variety of reasons for their movements: many of them are skilled workers and professionals, others enter after they have finished school and start their further education in Germany (Rat für Migration, 2016). These young students and professionals want to contribute to the economy, be successful, and are often motivated to start their own businesses. If they do so, their efforts are opportunity-driven and they choose Germany, among other reasons, for its flourishing entrepreneurial landscape. In present time, the self-employment rates of immigrants and Germans with an immigrant background are significantly higher than the rates of German business founders without any ethnical background (see Figure 3.1). Figure 3.1 shows that integration of immigrants into society is best achieved by self-employment and entrepreneurship. It seems that in Germany the barriers to being self-employed and to new venture creation are lower than entering the labor market. 


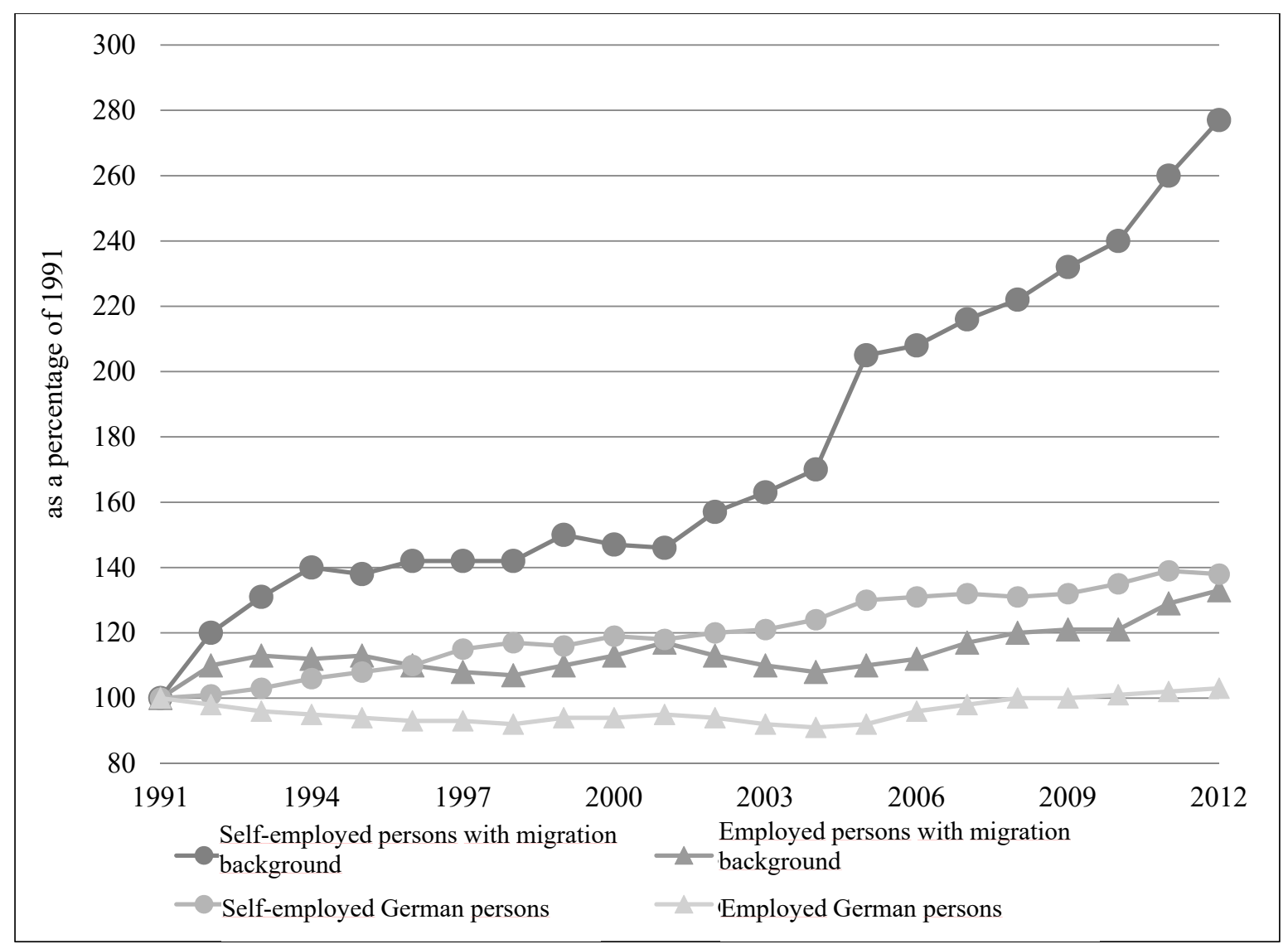

Figure 1: development of German and immigrated working population Source: Own presentation based on Leicht and Langhauser (2014)

Fostering economic growth by supporting entrepreneurial activities (Audretsch, Keilbach and Lehmann, 2006) could be part of the solution to the challenge of integrating immigrants into the labor market. New venture creation also leads to spillover effects which are almost neglected in official statistics: as the previous examples of the doner kebab and the spaghetti ice creams show, new venture creation by immigrants lead to employment effects for other immigrants. Thus, new venture creation and entrepreneurship is, indisputably, the trigger in fostering integration into society, and women, as the most dynamic and active persons, should be in the focus of this mechanism.

In the following section, we briefly describe Germany's entrepreneurial landscape and give a short overview of programs and political institutions supporting new venture creation and entrepreneurship with a focus on female immigrant entrepreneurship. 


\subsection{The Entrepreneurship Landscape in Germany}

Until recently, Germany itself has not been well known for its entrepreneurial spirit. Compared to other European countries or the United States, the number of newly initiated businesses has been lower and fewer people have tried to establish and develop their own ideas in a business start-up (see Figure 3.2).

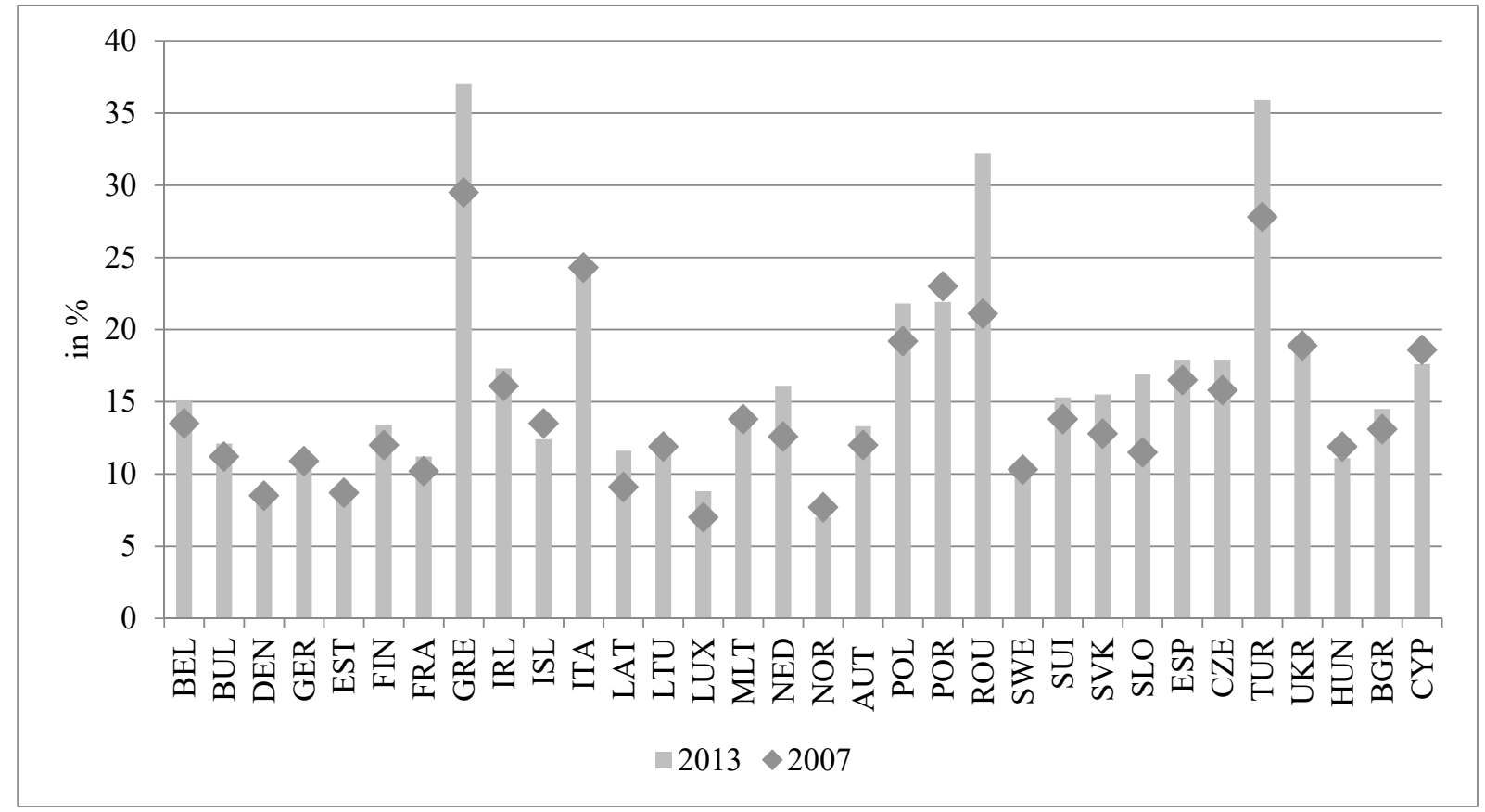

Figure 2: European comparisons of self-employed persons (percentage of working population)

Source: own presentation based on data from Statistisches Bundesamt (2015, 2014, 2013, 2012, 2011)

Stability, incrementalism, and long-term perspectives as well as the idea of establishing an business empire organized as a family business are the typical goals and ideas for German newly started businesses. New venture creation based on entrepreneurial dynamism, known from the start-up scene in Silicon Valley in the United States and other entrepreneurial hotspots, is at least unusual. Stability and continuity are preferred states in German businesses and society, which includes less tolerance of failure. Freedom of failing is restricted by law and society. Bankruptcy law prevents failed entrepreneurs from starting a new business in the six years following bankruptcy and they are forbidden to become CEOs of publicly traded corporations (for a broader discussion see Audretsch and Lehmann, 2016, pp. 34ff.). Therefore, high risk and uncertainty are avoided and rates of entrepreneurial failure are relatively low in Germany. Particularly in the last 30 years, thousands of German entrepreneurs left Germany 
and migrated to flourishing start-up regions like Silicon Valley, New York and other areas, mainly in the United States.

Because Germany's start-up rate comes below other countries, policy changes and institutional reforms have been initiated to ignite entrepreneurship. New programs include informational services as well as funding possibilities for new ventures. A particularly successful program is 'EXIST' (a funding program addressing students, graduates and scientist to support them in transforming their entrepreneurial ideas into business plans), which was initiated by the Federal Ministry of Economic Affairs and Energy with its focus on university spin-offs and start-ups (Bundesministerium für Wirtschaft und Energie, 2016a). The EXIST program unites key players from the relevant region, including nonprofit organizations, universities, government and entrepreneurs (Audretsch, Lehmann and Menter, 2016; Lehmann and Menter, 2016) to foster new venture creation. Focusing on regional clusters is a key element of the EXIST program. Each of these regions has a particular technological focus and unique set of partners with the goal of igniting high technology entrepreneurship in that region. Other programs fostering minorities in their entrepreneurial activities will be presented in the following section.

\subsection{Migration and Entrepreneurship in Germany: Some Facts and Figures}

Besides the above-mentioned opportunity-driven (high-tech) entrepreneurial activities, the perhaps more necessity-driven entrepreneurial undertakings by self-employed Germans are rising. The designation of 'necessity-driven' can be misleading in this context, because immigrant entrepreneurs often mention 'opportunities' as reasons for starting their business. The fact that they themselves see the possibility of starting their own venture as an opportunity shows that these categorizations vary depending on the point of view.

In total 284,000 business start-ups were registered in 2015 (Zeuner, 2016). As mentioned above, these rates are low, especially in an international comparison. However, these newly created businesses have an important impact on the labor market and positively influence economic growth, if only because these businesses employ their founders as well as other workers. These young businesses push innovation as well as internationalization, and if their founders have a migration background, they oftentimes use their relations and ties to connect their host and home countries (Ripsas and Tröger, 2016). The Federal Ministry of Economic Affairs and Energy report that 17.7 percent of all German entrepreneurs enter markets (regional, 
national or international) to establish totally new ideas (Bundesministerium für Wirtschaft und Energie, 2016b). A study about the German start-up scene proves that especially immigrants and women have a high potential for establishing new firms and becoming entrepreneurs (Ripsas and Tröger, 2016).

Besides a beneficial infrastructure with regional and local promoters of trade and industry, chambers of commerce and funding and supporting banks, many supporting institutions and programs, like the before mentioned EXIST and other programs addressing young women as well as men with an migration background, assist young latent and nascent entrepreneurs (Brixy, Sternberg and Vorderwülbecke, 2011). NOW, for example, initiated by the Commission of the EU in 1990, stands for 'New Opportunities for Women' and has the goal of supporting women in finding paid jobs and starting their own businesses by improving their education and training. INTEGRA, another program developed by the EU, exclusively targeted entrepreneurs with an ethnical background (Official Journal of the European Communities, 1990, 1996). The positive impact of the integration of migrants in labor markets by selfemployment was recognized by the German government leading to other political actions being taken. Advisory centers for self-employed persons with an ethnical background occurred in nearly all bigger cities and central platforms like the webpage 'www.exisitenzgruender.de', also initiated by the Federal Ministry of Economic Affairs and Energy, provide information about financial, legal and organizational affairs (Bundesministerium für Wirtschaft und Energie, 2016b). Especially because role models for female as well as immigrant entrepreneurs are often missing in the immediate environment, another political intervention seems to be very helpful: founder competitions. These initiatives create a competitive environment in which young nascent entrepreneurs compete for recognition and oftentimes trophy money. These competitions increase motivation and help to shed light on the ideas and creative conceptions of these young business starters (Bundesministerium für Wirtschaft und Technologie, 2013).

These policy efforts yield fruit. The share of entrepreneurs with an ethnical background rose over the last ten years to 44.8 percent, which represents 121,748 new venture initiations (see Figure 3.3). 


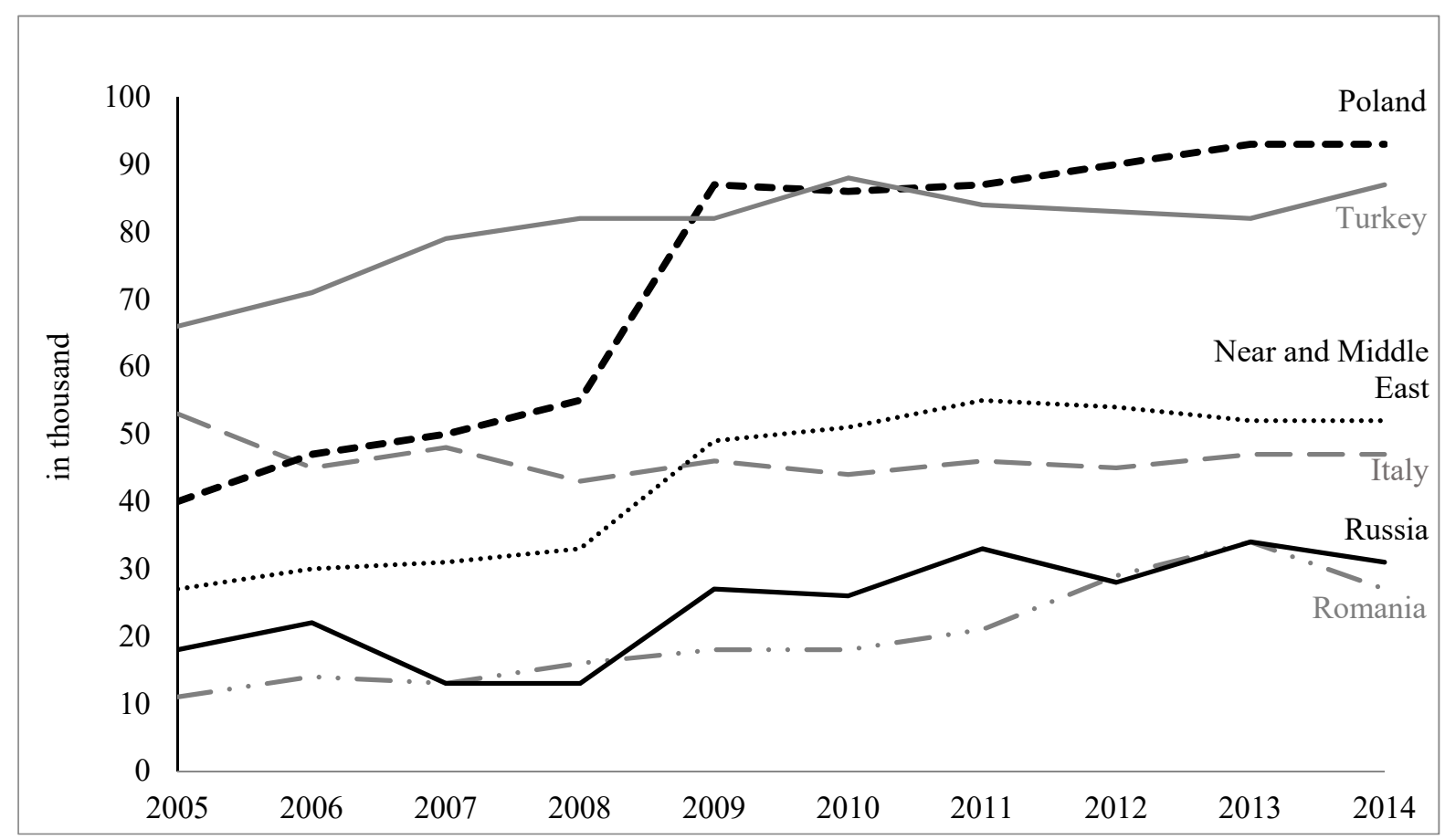

Figure 3: Self-employed persons and their origin countries Source: Own presentation based on data from Statistisches Bundesamt (2015, 2014, 2013, 2012, 2011).

A recent study (Bertelsmann Stiftung, 2016) reports the importance of immigrant startups for the German economy and job market. Between 2005 and 2014, the number of immigrant start-ups climbed from about 500,000 to over 700,000, employing in total more than 2 million people (an increase of 35 percent in the past ten years). While most of the new ventures are created in the service sectors, like catering, food and beverage, tourism, or traffic and transportation, plenty of new ventures are also created in the high-tech and knowledge-based sectors and the production sector. The study also reveals the importance of formal education. The higher the degree of formal education, the higher the percentage of self-employment and new venture creation, and the higher the number of people employed. These statistics will dramatically change due to the refugee crisis. The mentioned entrepreneurs with the mostly Eastern European background are mainly artisans and tradesmen. The newly arrived refugees from Syria, other Middle Eastern countries, and African countries have totally varying working and educational backgrounds, which will lead to versatility and a creative environment.

Nevertheless, integration processes as well as school and non-formal education should be improved to strengthen young women and immigrants in becoming entrepreneurs. Another aspect that pleads for growing entrepreneurial activities by immigrants is the fact that these inhabitants primarily live in cities. Brixy, Sternberg and Vorderwülbecke (2015) find that women as well as men living in metropolitan areas are more often involved in entrepreneurial 
activities and self-employment. The higher population density favors knowledge spillovers, provides a better infrastructure and offers a higher amount of qualified workers and service providers to support new venture creation. This is particularly important for nascent and active female immigrant entrepreneurs embedded in their cultural networks where they have access to scarce resources.

\section{Female Immigrant Entrepreneurship: Chances and Barriers}

How far these observations reflect the same opportunities for women and men will be discussed in the following. Theoretical considerations as well as empirical examinations indicate that, besides individual attitudes and characteristics, gender and ethnicity influence the probability of starting a new venture just as they influence success and failure rates of entrepreneurial activities. In this section, we will briefly introduce female entrepreneurship in general, and then focus on female immigrant entrepreneurship and the barriers to new venture creation for female immigrants.

Although female entrepreneurship is a growing research field, the reasons for the existing gender gap in entrepreneurial activities are not understood at all (Carter, 2000, 2016; Carter and Cannon, 1992; Bönte and Piegeler, 2013; Minniti, 2010; Minniti and Naude, 2010; Aidis et al., 2007; Vismara, Benaroio and Carne, 2016). All over the world (with the exception of some African, Latin American and Southeast Asian countries), women undertake fewer entrepreneurial activities and are less willing to start a new venture or become self-employed (Carter, 2000; Welter, 2016; Bönte and Piegeler, 2013; Kelley et al., 2014). Beside the fact that the general employment rate of women rose over time, which also led to higher selfemployment and entrepreneurial rates, the fact that there is latent potential for the welfare of countries changed political and social efforts to motivate women to realize their opportunities.

Ács et al. (2011) highlight that the nature and structure of entrepreneurial activities change over time and across countries. Besides other factors, a country's institutions influence and stimulate entrepreneurial activities. By describing institutions as the 'rules of the game' (Ács et al., 2011), and thereby giving them an informal and impalpable character, it becomes clear why women participate and perform in different ways (Estrin and Mickiewicz, 2011). Based on the assumption that entrepreneurial opportunities are spread over all fields of society as well as economy, individuals recognizing these opportunities can decide how to exploit them. Shane and Venkataraman (2000) distinguish between a market-based and a hierarchical 
solution: dependent on the opportunity and the industrial market structure, the entrepreneur could sell her/his idea to an existing firm or create her/his own business. Networks, the financial surroundings and access to capital, and social ties influence the entrepreneur's decision (Vismara, Benaroio and Carne, 2016; Lehmann, Seitz and Wirsching, 2016). Women perceive these environments in another way and are recognized differently as well, in general to their disadvantage. On the other hand, they are discriminated against in the labor market and miss the relations and networks that usually exist in corporations, wherefore a market-based solution is not feasible at all. Under these circumstances, the creation of an entrepreneurial environment that supports these women is important (Azmat, 2014).

Another strand of literature gives typical female characteristics and attitudes as reasons for the lower entrepreneurial engagement. Bönte and Piegeler (2013) use a data set based on interviews in 36 countries to investigate gender differences in nascent and latent entrepreneurship. Their hypotheses that women are less willing to take risks and tend to avoid competition can be confirmed and indicate that the gap between the number of female and male entrepreneurs can be explained by differences in these two personality characteristics. Other studies confirm the influence of fear of failure (Wagner, 2007) and risk aversion (Caliendo et al., 2014).

In Germany, women are still underrepresented, even if their total share of self-employed persons rose over the last thirty years to about 32 percent (Statistisches Bundesamt, 2015). Besides other circumstances, the fact that today generally more women are integrated in the labor market (their share is about 46 percent of the working population) provides a simple explanation (El Cherkeh and Tolciu, 2009).

As essential as new venture creation in the first step is, keeping the business running and performing well should be the higher aim. Results for survival durations, success and performance for businesses owned and managed by male and female entrepreneurs differ (Ahl, 2006; Jennings and Brush, 2013; Marlow and McAdam, 2013). Studies demonstrate shorter durations and a lower performance for women-owned businesses (Du Rietz and Henrekson, 2000) as well as no differences (Watson, 2002) and argue for the former that women's skills and preferences make the difference, whereas for the latter that existing differences concerning these skills and preferences are compensated for by running their business in a different way (Robb and Watson, 2012). By using empirical data about small businesses in Texas, Kalnins and Williams (2014) demonstrate that the businesses' geographic and industrial context 
influences the performance and survival duration of entrepreneurial firms. Particularly in large cities and urban areas, female-owned businesses in the service sector (for example educational or business services) out-survive male-owned businesses. They conclude that policy advice and programs fostering entrepreneurship should be coordinated and differentiated for branches and regions.

To complete the picture, a quick look at the next step of the business life cycle should be made, even though these firms are no longer entrepreneurial firms but rather family firms. For the time between the entrepreneurial and the succession period, studies find contradictory results concerning the impact of the gender of the manager. On the one hand, researchers found that management practices differ, which means that gender moderates the firms' performances (Danes, Stafford and Loy, 2007); on the other hand, female and male family business managers have the same adjustment strategies in turbulent times (Fitzgerald et al., 2001). The latter result is particularly surprising because it indicates that the typical role models do not play a role when it comes to troubles in the family or the business surroundings. As far as succession is concerned, female-led businesses have different plans concerning how to organize and plan the succession process (Harveston, Davis and Lyden, 1997). Apart from the comprehensiveness of the succession planning, the decision of who should become the successor is influenced by the gender of the former owner. Daughters face many challenges and are often ignored (Wang, 2010). Qualitative interviews indicate that these challenges and problems are more intense if the former business manager is a woman (Vera and Dean, 2005). A possible explanation for this observance could be found in the mother-daughter relationship, which is no longer restricted to their family relationship in the business succession process. However, as Rauf and Mitra (2011) show for female Pakistani immigrant entrepreneurs, the path dependence of cultural norms and ethnic ties are long lasting, shaping business success over generations. Focusing on female immigrants, prior literature substantiates more than one disadvantage concerning their opportunities to start their own businesses or participate in the labor market. Women face a glass ceiling in many organizations and are limited concerning their career paths (Cook and Glass, 2014; Estrin and Mickiewicz, 2011). Factors that inhibit female entrepreneurship are gender-based role models like their position within the family and the fact that they are responsible for child-rearing and household tasks (Parker, 2009). Additionally, female immigrants are often disadvantaged with regard to any labor market activity due to their ethnical background. These disadvantages can also affect resulting relations to business partners and support facilities. By interviewing 40 Black, Asian and minority ethnic female business owners in England, Davidson, Fielden and Omar (2010) figure out that more than half of their 
participants had experienced discrimination. Their gender as well as their ethnical background and underlying stereotypical images led to disadvantages in accessing different types of social support and a lack of resources. Basu (1998) finds out that especially the access to informal sources of capital and information is important for successful business entry. Using World Bank Enterprise Survey data, Bardasi, Sabarwal and Terrell (2011) analyze performance differences between male- and female-owned companies in three regions - Eastern Europe and Central Asia, Latin America, and Sub-Saharan Africa - and find significant gaps between male- and female- owned companies in terms of firm size, firm efficiency and growth (except in Latin America). They argue that women run smaller firms because they tend to concentrate in sectors in which firms are smaller and less efficient.

Summing up, female immigrant entrepreneurs meet challenges and disadvantages due to their ethnic background, wherefore they are so-called double disadvantaged (Davidson, Fielden and Omar, 2010). They have to struggle with discrimination based on gender and ethnicity. Restricted access to information because of their absent language skills, inappropriate or inadequate human capital such as cultural information, and a limited knowledge about the labor market make it difficult for them to integrate and participate. In particular, absent language skills discourage women from typically female-dominated occupations like teacher, clerk or sales assistant. Raijman and Semyonov (1997) find that female immigrant entrepreneurs' land of origin matters as well: if these women immigrate from a developing country, they face a 'triple disadvantage'. Apart from disadvantages reduced to gender and the divergent ethnic background, women from developing countries have to overcome greater differences in social and private life (Raijman and Semyonov, 1997). They often come from societies that are more traditional to modern Western countries and have to learn how to handle common practices. Besides the negative impact of every individual disadvantage, these women could be affected by interdependencies. Intersectionality theory describes the consequences of being discriminated against for more than one identity category and the intragroup differences that lead to multifaceted forms of discrimination (Crenshaw, 1991). Consequently, structures and policy interventions that should foster female entrepreneurship could exclude female immigrant entrepreneurs, for example simply because of language barriers. Additionally, programs addressing immigrant entrepreneurs could exclude women because of specific requirements like attendance during the day, which could conflict with child-caring. This intersectionality affects particularly female immigrants from developing countries. 
In order to gain a better understanding of why these female immigrants still become entrepreneurs, the reasons and motives of these women must be taken into consideration. Today, there are many different typologies of entrepreneurial motivations (for an overview see Stephan, Hart and Drews, 2015). One of the first established differentiations in the entrepreneurship literature was the one between necessity- and opportunity-driven entrepreneurship as mentioned above (Stoner and Fry, 1982). This differentiation recognizes that entrepreneurship, on the one hand, could be premised on an opportunity which brings an advantage to the entrepreneur her/himself, and she/he her/himself pushes the idea. On the other hand, entrepreneurship can be a reaction to job loss or the absence of other types of employment, and consequently arises from necessity. This view regularly assumes that necessity-driven entrepreneurs are less educated and have a lower level of skills, which as a result should lead to lower success rates and shorter survival times for these businesses. This equation could be an oversimplification, particularly if the unemployment rates in an economy are generally high or if the nascent entrepreneurs are discriminated against in the labor market (Stephan, Hart and Drews, 2015). With regard to the second argument, female immigrant entrepreneurs are often in the situation where starting their own venture is the obvious way to work and earn money. Estrin, Mickiewicz and Stephan (2013) determine that women tend to engage in social entrepreneurship rather than commercial entrepreneurship, which also indicates that they are more necessity-driven and followers of innovative ideas or technological improvements.

Summarizing the sections above, it has to be said that gender as well as the ethnical background of entrepreneurs matters. Current research shows that besides entrepreneurial skills and the economic and political environment, the two attributes of being female and having a migrant background can be barriers for carrying out entrepreneurial activities. How far the interplay of these attributes intensifies the negative impact is practically unknown. Collins and Low (2010) emphasize that gender dimensions are often ignored in the literature on ethnic or immigrant entrepreneurship and the literature on female/gender entrepreneurship often ignores ethical aspects. This holds for possible interactions and exponentiation effects of other barriers, too. Azmat (2014) mentions seven possible barriers faced by migrant women entrepreneurs, namely: 'institutional factors', such as regulation and support factors; 'culture', similarly to religion, values and norms; 'family'; 'human capital', meaning business experience and education; 'social capital', indicating informal ties; 'race and ethnicity'; and lastly 'gender'. 
These barriers are obviously interconnected, for example because religious norms include role models concerning the family as well as gender and influence institutional conventions and regulations. Muslim societies tend to separate women and protect their honor, which is why they have strong family ties and females have their role in society primarily in the kinship. Women are typically dominated by their male siblings or husbands and are more inflexible concerning spatial and social changes (Roomi and Parrott, 2008). Immigrants or minorities with this ethnic background are oftentimes discriminated against or at least not supported by institutions in their host countries (Heilbrunn, Abu-Asbeh and Nasra, 2014).

The major barriers, however, are seen in gender differences, grounded in the cultural and familiar background. Gender-based differences in the networking method, the social context and intra- and inter-familiar division of labor affect both employment and selfemployment activities. Women in different societies have been assigned different roles. Women tend to be the kin-keepers in families, organizing family events and staying in touch with distant kin. Tasks associated with working in the home also tend to persist even for women working outside the home (Wellman and Wellman, 1992). Relations with kin and neighbors, also in the host countries, tend to be more important to women than to men and are of much practical and psychological importance (Bastani, 2007; Rauf and Mitra, 2011), which determines the network characteristics of men and women. While females are more conservative in their network practices, men are bolder and make their choices confidently as compared to women (Hodgetts and Hegar, 2007), while female networks consists of fewer but stronger ties (Hisrich and Brush, 1986). Otherwise, these ethnic ties in their networks often restrict women in conducting their business. The cultural norm of the 'protective males' is often reflected in the co-ownership of entrepreneurial ventures, where dealing with customers and suppliers is normally taken care of by the male relatives or the husband (Rauf and Mitra, 2011). Female immigrant entrepreneurs are often restricted by their males, who are typically seen as 'very demanding', believing that the role of a female is specified by culture. Thus, the males do not encourage the females' career aspirations (Rauf and Mitra, 2011, p. 13).

The choice of the sector also depends on the motive to start a business. Less educated women having limited knowledge of business are often restricted to products and services they are acquainted to such as clothing or food (Lofstrom, 2009). While this holds in general for all entrepreneurs, female immigrant entrepreneurs are additionally restricted to a business that holds a socially positive image. As Rauf and Mitra (2011, p. 14) point out, some services, like beauticians, are strongly opposed and considered a stigma to the family. The traditional role of 
immigrant female entrepreneurs limits the sphere regarding the choice of business sectors, working hours outside home and networking behavior. Because of such a socially constructed gender role, female immigrant entrepreneurs are often housewives, acquiring skills in the traditional household chores which they translate into mini-scale business ventures, like catering and food trading, clothing repair and retail, and wholesaling and other services close to home. Thus, immigrant female entrepreneurs often have a dual responsibility for household activities and work. Particularly women from southern European and Middle Eastern countries appear seldomly at the labor market and almost never as entrepreneurs (Leicht and Langhauser, 2014; Statistisches Bundesamt, 2015). Classical role models, family ties and a general segregation from working positions and higher education opportunities can be explanations for this structural problem. The point that these women are often responsible for their families and therefore have decreased access to entrepreneurial human capital should especially be considered when policy efforts try to integrate female immigrant entrepreneurs (McManus, 2001). Another explanation could be that women generally avoid competition and consequently do not pursue their entrepreneurial opportunities (Bönte and Piegeler, 2013). Additionally, fear of failure and risk aversion hamper new business creation (Caliendo et al., 2014; Wagner, 2007).

\section{SUMMARY AND CONCLUSION}

Particularly because the relevant barriers on the one hand and motives and reasons on the other are to a large extend unknown, female immigrant entrepreneurship should be on the research agenda in the flourishing field of entrepreneurship. Germany, as a historically constituted migration country, is a good example of the importance of integration for economic development as well as a functioning society in a social market economy. Even though a look back through time shows rising entrepreneurship rates and an increasing integration of women in labor markets, the refugee crisis and globalization in general demand sustainable and holistic concepts to foster these developments. The present chapter gives a brief overview of existing literature as well as facts and figures about female immigrant entrepreneurship in Germany. Additional data and focused surveys should try to interconnect the minority groups of women and immigrants to gain a better understanding of needs and barriers.

Against the background that the refugee crisis mainly concerns the Middle Eastern countries, a main task for the future is to create an entrepreneurial and social environment that promotes and supports the integration and development of the ideas of and opportunities for 
female immigrants. The scare evidence shows that self-employment and new venture creation by immigrants has been one of the most successful mechanisms of integrating these people into society. Despite language problems and administrative hurdles, the barriers to entering selfemployment and new venture creation are seen to be lower than entering the traditional labor market. German policy should implement a holistic approach to benefit from these women and foster economic growth and social welfare. 


\section{REFERENCES}

Ács, Z.J., Bardasi, E., Estrin, S. and J. Svejnar (2011), 'Introduction to special issue of Small Business Economics on female entrepreneurship in developed and developing economies', Small Business Economics, 37(4), 393-396.

Ahl, H. (2006), 'Why research on women entrepreneurs needs new directions', Entrepreneurship Theory and Practice, 30(5), 595-621.

Aidis, R., Welter, F., Smallbone, D. and N. Isakova (2007), 'Female entrepreneurship in transition economies: The case of Lithuania and Ukraine', Feminist Economics, 13(2), 157-183.

Aldrich, H., Resse, P. and P. Dubini (1989), 'Women on the verge of a breakthrough: Networking between entrepreneurs in the United States and Italy', Entrepreneurship and Regional Development, 1, 339-356.

Audretsch, D.B., Keilbach, M.C. and E.E. Lehmann (2006), Entrepreneurship and economic growth, New York: Oxford University Press.

Audretsch, D.B. and E.E. Lehmann (2016), The seven secrets of Germany: Economic resilience in an era of global turbulence, New York: Oxford University Press.

Audretsch, D.B., Lehmann, E.E. and M. Menter (2016), 'Public cluster policy and new venture creation', Journal of Industrial and Business Economics (Economia e Politica Industriale), 43(4), 357-381.

Azmat, F. (2014), 'Migrant women entrepreneurs: Exploring the barriers', in L. Kelly (ed.), Entrepreneurial women: New management and leadership models, Santa Barbara, CA: ABCCLIO, pp. 199-217.

Bardasi, E., Sabarwal, S. and K. Terrell (2011), 'How do female entrepreneurs perform? Evidence from three developing regions', Small Business Economics, 37, 417-441.

Bastani, S. (2007), 'Family comes first: Men's and women's personal networks in Tehran', Social Networks, 29(3), 357-374.

Basu, A. (1998), ‘An exploration of entrepreneurial activity among Asian small businesses in Britain', Small Business Economics, 10, 313-326. 
Bertelsmann Stiftung (2016), Migrantenunternehmen sind Jobmotor für Deutschland, accessed 10 August 2016 at https://www.bertelsmann-stiftung.de/de/themen/aktuellemeldungen/2016/august/migranten unternehmen-sind-jobmotor-fuer-deutschland/.

Bönte, W. and M. Piegeler (2013), 'Gender gap in latent and nascent entrepreneurship: Driven by competitiveness', Small Business Economics, 41(4), 961-987.

Brixy, U., Sternberg, R. and A. Vorderwülbecke (2011), 'Unternehmensgründungen von Migranten: Ein Weg zur ökonomischen und sozialen Integration', IAB Kurzbericht, 8/2011.

Brixy, U., Sternberg, R. and A. Vorderwülbecke (2015), 'Gründungen sind selten Frauensache', Selbstständigkeit in Ost-und Westdeutschland, IAB Kurzbericht, 10/2015.

Bundesamt für Migration und Flüchtlinge (2006), Definition of migration and of migrants, accessed 02 June 2016 at http://www.bpb.de/gesellschaft/migration/kurzdossiers/58038/definition.

Bundesamt für Migration und Flüchtlinge (2015), Migrationsbericht 2014, accessed 05 June 2016 at http://www.bamf.de/SharedDocs/Anlagen/DE/Publikationen/Migrationsberichte/migrationsbe richt-

2015.html;jsessionid=11D4632CD08941797C2D8FC9E5333520.1_cid359?nn=1663558.

Bundesamt für Migration und Flüchtlinge (2016), Das Bundesamt in Zahlen 2015 - Asyl, accessed 02 June 2016 at http://www.bamf.de/SharedDocs/Anlagen/DE/Publikationen/Broschueren/bundesamt-inzahlen-2015-asyl.html?nn=1694444.

Bundesministerium für Wirtschaft und Energie (2016a), EXIST - University-based business start-ups, accessed 10 June 2016 at http://www.exist.de/DE/Programm/Ueber-Exist/inhalt.html.

Bundesministerium für Wirtschaft und Energie (2016b), Gründer/innen mit Migrationshintergrund, accessed 15 June 2016 at http://www.existenzgruender.de/DE/Service/BeratungAdressen/Linksammlung/

Gruender-innen-Migrationshintergrund/inhalt.html.

Bundesministerium für Wirtschaft und Technologie (2013), Gründerland Deutschland: Zahlen und Fakten. Unternehmensgründungen und Gründergeist in Deutschland, accessed 15 June 2016 at http://www.bmwi.de/DE/Mediathek/publikationen,did=446924.html. 
Caliendo, M., Fossen, F.M., Kritikos, A. and M. Wetter (2014), 'The gender gap in entrepreneurship: Not just a matter of personality', CESifo Economic Studies, Munich.

Carter, S. (2000), 'Gender and enterprise', in S. Carter and D. Jones-Evans (eds), Enterprise and small business: Principles, practice and policy, Harlow, UK: Prentice Hall/Pearson Education Limited.

Carter, S. (2016), 'The effects of business ownership on people's lives', in D.B. Audretsch and E.E. Lehmann (eds), Routledge companion on makers of modern entrepreneurship, London: Routledge, pp. 42-52.

Carter, S. and T. Cannon (eds) (1992), Women as entrepreneurs, London: Academic Press.

Collins, J. and A. Low (2010), 'Asian female immigrant entrepreneurs in small and medium-sized businesses in Australia', Entrepreneurship and Regional Development, 22(1), 97-111.

Cook, A. and C. Glass (2014), 'Women and top leadership positions: Towards an institutional analysis', Gender, Work and Organization, 21(1), 91-103.

Crenshaw, K. (1991), 'Mapping the margins: Intersectionality, identity politics, and violence against women of color', Stanford Law Review, 43, 1241-1299.

Danes, S.M., Stafford, K. and J.T.-C. Loy (2007), 'Family business performance: The effects of gender and management', Journal of Business Research, 60(10), 1058-1069.

Davidson, M.J., Fielden, S.L. and A. Omar (2010), 'Black, Asian and minority ethnic female business owners: Discrimination and social support', International Journal of Entrepreneurial Behavior and Research, 16(1), 58-80.

Du Rietz, A. and M. Henrekson (2000), 'Testing the female underperformance hypothesis', Small Business Economics, 14(1), 1-10.

Dustmann, C. and J.-S. Görlach (2016), 'Estimating immigrant earnings profiles when migrations are temporary', CESifo Working Paper No. 5919, May 2016.

El-Cherkeh, T. and A. Tolciu (2009), 'Migrant entrepreneurs in Germany: Which role do they play?', HWWI Policy Paper. 
Estrin, S. and T. Mickiewicz (2011), 'Institutions and female entrepreneurship', Small Business Economics, 37(4), 397-415.

Estrin, S., Mickiewicz, T. and U. Stephan (2013), 'Entrepreneurship, social capital, and institutions: Social and commercial entrepreneurship across nations', Entrepreneurship Theory and Practice, 37(3), 479-504.

Fitzgerald, M., Winter, M., Miller, N. and J. Paul (2001), 'Adjustment strategies in the family business: Implications of gender and management role', Journal of Family and Economic Issues, 22(3), $265-291$.

Fontanella (2016), Eis Fontanella, 1906 - heute, accessed 10 August 2016 at http://eisfontanella.de/about/.

Frankfurter Rundschau (2011), Interview mit dem Erfinder des Doener: 'Echt nur mit Zwiebeln und Salat', accessed 10 August 2016 at http://www.fr-online.de/panorama/interview-mit-demerfinder-des-doener--echt-nur-mit-zwiebeln-undsalat-,1472782,10892314.html.

Harding, R. (2004), 'Social enterprise: The new economic engine?', Business Strategy Review, 15, 3943.

Harding, R. and N. Bosma (2006), 'Global entrepreneurship monitor 2006 results', Babson College and London Business School, Babson Park, Wellesley, MA.

Harveston, P.D., Davis, P.S. and J.A. Lyden (1997), 'Succession planning in family business: The impact of owner gender', Family Business Review, 10(4), 373-396.

Heilbrunn, S., Abu-Asbeh, K. and M.A. Nasra (2014), 'Difficulties facing women entrepreneurs in Israel: A social stratification approach', International Journal of Gender and Entrepreneurship, 6(2), 142-162.

Hisrich, R. and C. Brush (1986), 'Characteristics of the minority entrepreneur', Journal of Small Business Management, 24, 1-8.

Hodgetts, R. and K. Hegar (2007), Modern human relations at work, Mason, OH: Cengage Learning, Inc.

Jennings, J.E. and C.G. Brush (2013), 'Research on women entrepreneurs: Challenges to (and from) the broader entrepreneurship literature?', Academy of Management Annals, 7(1), 663-715. 
Kalnins, A. and M. Williams (2014), 'When do female-owned businesses out-survive male-owned businesses? A disaggregated approach by industry and geography', Journal of Business Venturing, 29(6), 822-835.

Kelley, D., Brush, C., Greene, P., Herrington, M., Ali, A. and P. Kew (2014), Global entrepreneurship monitor women's report: GEM, accessed 10 June 2016 at http://www.gemconsortium.org.

Kontos, M. (2003), 'Self-employment policies and migrants' entrepreneurship in Germany', Entrepreneurship and Regional Development, 15(2), 119-135.

Lehmann, E.E. and M. Menter (2016), 'University-industry collaboration and regional wealth', Journal of Technology Transfer, 41(6), 1284-1307.

Lehmann, E.E., Seitz, N. and K. Wirsching (2016), 'Smart finance for smart places to foster new venture creation', Journal of Industrial and Business Economics (Economia e Politica Industriale). DOI 10.1007/s40812-016-0052-7.

Leicht, R. and M. Langhauser (eds) (2014), Ökonomische Bedeutung und Leistungspotenziale von Migrantenunternehmen in Deutschland: Studie im Auftrag der Abteilung Wirtschafts-und Sozialpolitik, Arbeitskreis Mittelstand und Gesprächskreis Migration und Integration der Friedrich-Ebert-Stiftung, Friedrich-Ebert-Stiftung.

Lofstrom, M. (2009), ‘Low-skilled immigrant entrepreneurship', IZA Discussion Paper No. 4560.

Marlow, S. and M. McAdam (2013), 'Gender and entrepreneurship: Advancing debate and challenging myths; exploring the mystery of the under-performing female entrepreneur', International Journal of Entrepreneurial Behavior and Research, 19(1), 114-124.

McManus, P. (2001), 'Women's participation in self-employment in Western industrialized nations', International Journal of Sociology, 31(2), 70-97.

Minniti, M. (2010), 'Female entrepreneurship and economic activity', European Journal of Development Research, 22(3), 294-312.

Minniti, M. and W. Naude (2010), 'What do we know about the patterns and determinants of female entrepreneurship across countries?', European Journal on Development Research, 22(3), 277293. 
Möhring, M. (ed.) (2012), Fremdes Essen. Die Geschichte der ausländischen Gastronomie in der Bundesrepublik Deutschland, München: Oldenbourg Wissenschaftsverlag Verlag.

OECD (2015a), International migration outlook 2015, Paris: OECD Publishing.

OECD (2015b), Talent abroad: A review of German emigrants, Paris: OECD Publishing.

Official Journal of the European Communities (1990), No. C 32715, 29 December 1990.

Official Journal of the European Communities (1996), No. C 200/20, 10 July 1996.

Parker, S.C. (2009), The economics of entrepreneurship, Cambridge: Cambridge University Press.

Raijman, R. and M. Semyonov (1997), 'Gender, ethnicity, and immigration: Double disadvantage and triple disadvantage among recent immigrant women in the Israeli labor market', Gender and Society, 11(1), 108-125.

Rat für Migration (2016), Mediendienst Integration: Wer kommt, wer geht?, accessed 15 June 2016 at http://mediendienst-integration.de/migration/wer-kommt-wergeht.html.

Rauf, A. and J. Mitra (2011), 'Role of personal networks in the growth of entrepreneurial ventures of ethnic minority female entrepreneurs', CER Working Paper Series on Entrepreneurship and Innovation, WP 5, Essex Business School.

Ripsas, S. and S. Tröger (2016), Deutscher startup monitor 2015, accessed 15 June 2016 at http://deutscherstartupmonitor.de/dsm/dsm-15/.

Robb, A.M. and J. Watson (2012), 'Gender differences in firm performance: Evidence from new ventures in the United States', Journal of Business Venturing, 27(5), 544-558.

Roomi, M.A. and G. Parrott (2008), 'Barriers to development and progression of women entrepreneurs in Pakistan', Journal of Entrepreneurship, 17(1), 59-72.

Shane, S. and S. Venkataraman (2000), 'The promise of entrepreneurship as a field of research', Academy of Management Review, 25(1), 217-226.

Spiegel online (2011), Kadir Nurman: Döner-Erfinder mag keine Tomaten im Fladenbrot, accessed 10 August 2016 at http:/www.spiegel.de/panorama/leute/kadir-nurman-doener-erfinder-magkeine-tomaten-im-fladenbrot-a-788153.html. 
Statistisches Bundesamt (2011), Statistisches Jahresbuch. Deutschland und Internationales 2011, $\begin{array}{llll}\text { accessed } & 05 & \text { June } & 2016\end{array}$ https://www.destatis.de/DE/Publikationen/StatistischesJahrbuch/StatistischesJahrbuch 2011.pdf?_blob=publicationFile.

Statistisches Bundesamt (2012), Statistisches Jahresbuch. Deutschland und Internationales 2012, $\begin{array}{lllll}\text { accessed } & 05 & \text { June } & 2016\end{array}$ https://www.destatis.de/DE/Publikationen/StatistischesJahrbuch/StatistischesJahrbuch 2012.pdf?_blob=publicationFile.

Statistisches Bundesamt (2013), Statistisches Jahresbuch. Deutschland und Internationales 2013, $\begin{array}{llll}\text { accessed } & 05 & \text { June } & 2016\end{array}$ https://www.destatis.de/DE/Publikationen/StatistischesJahrbuch/StatistischesJahrbuch 2013.pdf? blob=publicationFile.

Statistisches Bundesamt (2014), Statistisches Jahresbuch. Deutschland und Internationales 2014, $\begin{array}{lllll}\text { accessed } & 05 & \text { June } & 2016\end{array}$ https://www.destatis.de/DE/Publikationen/StatistischesJahrbuch/StatistischesJahrbuch 2014.pdf?_blob=publicationFile.

Statistisches Bundesamt (2015), Statistisches Jahresbuch. Deutschland und Internationales 2015, $\begin{array}{lllll}\text { accessed } & 05 & \text { June } & 2016\end{array}$ https://www.destatis.de/DE/Publikationen/StatistischesJahrbuch/StatistischesJahrbuch 2015.pdf?_blob=publicationFile.

Statistisches Bundesamt (2016), Wanderungen zwischen Deutschland und dem Ausland 1991-2014, $\begin{array}{lllll}\text { accessed } & 15 & \text { June } & 2016\end{array}$ https://www.destatis.de/DE/ZahlenFakten/GesellschaftStaat/Bevoelkerung/ Wanderungen/Tabellen/WanderungenAlle.html.

Stephan, U., Hart, M. and C.-C. Drews (2015), Understanding motivations for entrepreneurship: A review of recent research evidence, Enterprise Research Centre.

Stern (2014), Der Mann, der das Spaghettieis erfand, accessed 10 August 2016 at http://www.stern.de/genuss/beliebter-eisklassiker-wird-45-der-mann-der-dasspaghettieiserfand-2093388.html. 
Stoner, C.R. and F.L. Fry (1982), 'The entrepreneurial decision: Dissatisfaction or opportunity', Journal of Small Business Management, 20(2), 39-44.

Vera, C.F. and M.A. Dean (2005), 'An examination of the challenges daughters face in family business succession', Family Business Review, 18(4), 321-345.

Verheul, I. and R. Thurik (2001), 'Start-up capital: “Does gender matter?”, Small Business Economics, 16(4), 329-346.

Vismara, S., Benaroio, D. and F. Carne (2016), 'Gender in entrepreneurial finance: Matching investors and entrepreneurs in equity crowdfunding', in A. Link (ed.), Gender and entrepreneurial activity, Cheltenham, UK and Northampton, MA, USA: Edward Elgar Publishing.

Wagner, J. (2007), 'What a difference a Y makes - Female and male nascent entrepreneurs in Germany', Small Business Economics, 28(1), 1-21.

Wang, C. (2010), 'Daughter exclusion in family business succession: A review of the literature', Journal of Family and Economic Issues, 31(4), 475-484.

Watson, J. (2002), 'Comparing the performance of male- and female-controlled businesses: Relating outputs to inputs', Entrepreneurship Theory and Practice, 26(3), 91-100.

Wellman, B. and B. Wellman (1992), 'Domestic affairs and network relations', Journal of Social and Personal Relationships, 9(3), 385-409.

Welter, F. (2016), 'Wandering between contexts', in D.B. Audretsch and E.E. Lehmann (eds), Routledge companion on makers of modern entrepreneurship, London: Routledge, pp. 213232.

Zeuner, J. (eds) (2016), KfW Gründungsmonitor, Frankfurt am Main: Kreditanstalt für Wiederaufbau. 